\title{
The effects of one day wrestling tournament on muscle damage and delayed onset muscle soreness of male wrestlers
}

\author{
Ismail Kaya ${ }^{1 \mathrm{a}}$ \\ ${ }^{1}$ Dumlupinar University School of Physical Education and Sport, Kutahya, Turkey
}

\begin{abstract}
The aim of this study was to investigate muscle damage and following delayed onset muscle soreness of elite wrestlers after one-day wrestling tournament. The study sample consists of 20 male wrestlers from Dumlupinar University School of Physical Education and Sports who are the contestant and have national degrees. The wrestlers voluntarily participated in the study. Measurements of the sampling group's features such as height and weight etc. were made after 12 weeks of preparation and 3 days of rest before the one-day competition. Venous blood samples were taken from the wrestlers before the first competition and after the fifth competition and serum, Creatine Kinase values were measured. In the evaluation of pre and post tournament measurement results, dependent samples t-test was applied at $\% 99$ significance value and Likert-type pain scale was used in order to determine muscle pain of the wrestlers. The wrestlers were asked to specify their muscle pain from 0 (no pain) to 10 (the most severe pain) and pain values of the wrestlers were determined before the competition, after the 1st, 3rd, 5th competitions and after 24 and 48 hours. Analyze results revealed that creatine kinase level of the wrestlers was $(155.35 \pm 44.89)$ before the tournament and $(644.50 \pm$ 216.73) after the tournament and both creatine kinase level and muscle pain values significantly increased after the tournament. As a result, this study showed that after one day wrestling tournament muscle damage occurs in wrestlers and even after 48 hours following muscle pain continues.
\end{abstract}

Keywords: Wrestling, Muscle Damage, Creatine Kinase, Delayed onset Muscle Soreness

\section{Introduction}

Wrestling is one of the most common individual sports in the world [19] and among bilateral fighting sports, wrestling was an important part of the Ancient Olympics and it is still one of the most popular contests in the Modern Olympic Games [8]. Wrestling is a kind of sport in which the anaerobic energy system predominantly used and, factors such as speed, flexibility, balance, muscular and cardiovascular durability and coordination effects

\footnotetext{
${ }^{\text {a }}$ Corresponding author: ismail.kaya@dpu.edu.tr
} 
the performance, requires a great deal of power and energy during training and competition [3]. Sportsmen aim to maximize their performances with training [18]. And in wrestling, anaerobic power and capacity are both important because of the short-term and highintensity performance requirements. Anaerobic metabolisms, especially glycolytic changes, are fundamentals in the energy distribution to the muscles [14]. Conscious exercises are effective in the fall of the blood pressure, reducing the loss of muscle and the bone mass [15].

Damage to muscles after exercise causes muscle-specific components to migrate from membrane ruptures into the bloodstream. In such cases, the most common component seen in the blood is the creatine kinase (CK). Besides, another indicator of muscle damage is elevated serum lactate dehydrogenase (LDH) level [17].

Wrestling is one of the most demanding sports of skeletal, muscular and cardio-vascular systems [7]. As a result of intense exercises performed in a short time, it is possible that some damages and aches occur in the muscles. Since all the systems of the organism work at the maximal level of a wrestling competition or in heavy training sessions, this condition is explained as muscle damage.

In the studies which aimed to investigate both skeleton and myocardium damage, commonly looked through the creatine kinase and its' sub isomorphs; myoglobin, aspartate aminotransferase (AST), lactate dehydrogenase (LDH), brain natriuretic peptide (BNP), atrial natriuretic peptide (ANP), carbonic anhydrase, lactate dehydrogenase, troponin and muscle building proteins. Among these enzymes creatine kinase is perhaps the most important and most commonly used enzyme. Because creatine kinase is the enzyme which regenerates the ATP in the contraction and transportation systems. Creatine kinase becomes physiologically functional in the muscle cell and as a result, ATP is formed using creatine phosphate in each contraction cycle of the muscle. This result keeps muscle ATP level steady and in this returning reaction, creatine kinase acts as a catalyst [10]. When examined the studies, investigating the relationship of strength training and its damage in the skeleton muscle and the muscle pain in sedentary individuals, it can be said that creatine kinase as an indicator of muscle damage and pain values increases after training. It was also found that it peaked 24 hours after the training, started falling at 48 hours, and at the $72^{\text {nd }}$ hour, it reached a parallel level to the level just after exercise [11].

Three types of muscle damage are known to be present in the long-running period, continuing or intermittent severe contractions. The first and most commonly observed of the three types of muscle damage is known as delayed onset muscle soreness and according to this type of muscle soreness individuals complain of feeling weakness, tiredness and tenderness starting from the muscles after 12-48 hours of exercise [2].

In order to be successful in a fighting sport such as wrestling, it is necessary to maintain very heavy training for a long time. But it is observed that sudden decreases in the performance of wrestlers who have been exposed to long and high-intensity exercises. These decreases, which causes swelling in the sportsmen, is a condition that causes muscle exhaustion, loss of function, weakness, and pain after severe exercises ([5], [13]). Part of the responses to the situations mentioned above such as muscle exhaustion etc. is the process of filtering macrophages into damaged tissue. As a result these macrophages result in free radicals causing greater damage. But increased antioxidant content can theoretically neutralize these radicals and thus reduce muscle damage and muscle pain [1]. 


\section{Material and method}

\subsection{Study sample}

20 male wrestlers, who are the contestant and have degrees at the national level from various departments of Dumlupinar University School of Physical Education and Sports voluntarily, participated in the study. The mean age of sampling group is $21.55 \pm 1.61$ years and means height is $175.81 \pm 8.97 \mathrm{~cm}$, mean body height $77.75 \pm 11.25 \mathrm{~kg}$ and mean age of training is $7.45 \pm 2.06$ years. Measurements of the sampling group's features such as height and weight etc. were made after 12 weeks of preparation and 3 days of rest before the tournament.

\subsection{Procedure}

Venous blood samples were taken from the subjects before the first competition and after the fifth competition. Creatine Kinase level of the serums obtained from centrifuging blood was assessed with using Hitachi 912 biochemical device with Roche Diagnostic kit. In order to evaluate the subjects' muscle pain, Likert-type pain scale was used. The subjects were asked to specify their muscle pain from 0 (no pain) to 10 (the most severe pain) and pain values of the subjects were determined before the first competition, after the 1st, 3rd, 5th competitions and after 24 and 48 hours.

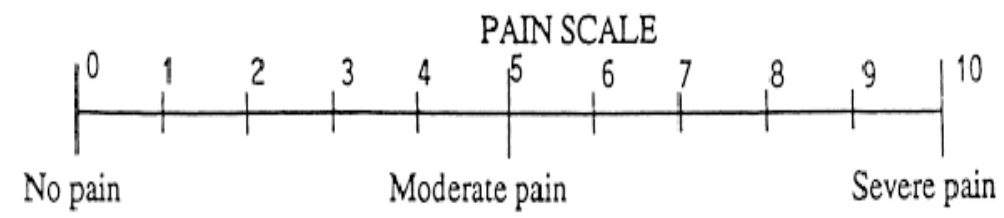

Figure 1. Likert-Type Pain Scale (Source: [9]).

One day wrestling tournament, suitable for the international wrestling rules and international tournament guidelines was designed for the wrestlers. All the participants participated in all five competitions regardless of whether they won or not. The rest periods between competitions are shown in Figure 2.

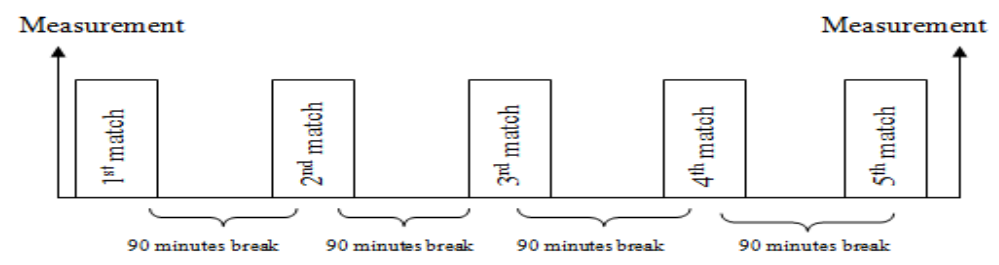

Figure 2. Tournament Chart

\subsection{Statistical analyze}

The obtained data was evaluated with SPSS version 20.0 Package Program. In order to evaluate the homogeneity of the data normality tests were done and in order to evaluate creatine kinase level before and after the competitions paired samples t-test was done. Also in order to evaluate demographic features and pain values of the wrestlers' descriptive statistics were used. 


\section{Findings}

Graph 1. Creatine Kinase levels

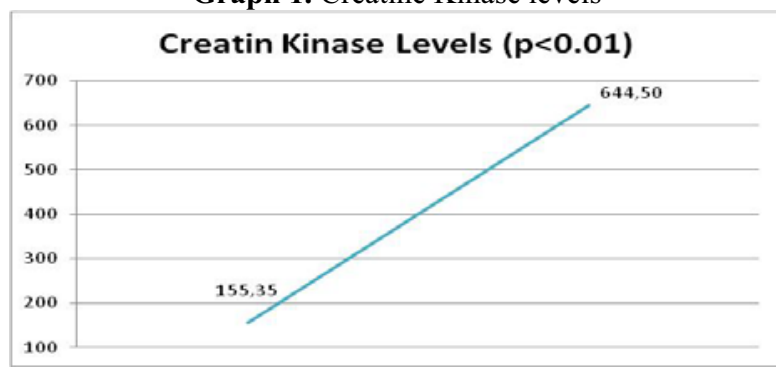

According to normality test results, it was seen that the obtained data for creatine kinase level was normally distributed and in order to evaluate significant differences between creatine kinase levels for the participants' dependent samples t-test was used at \%99 significance level. Analyze results revealed that the increase of the creatine kinase levels between the pre $(155.35 \pm 44.89)$ and post $(644.50 \pm 216.73)$ measurements was significant $(\mathrm{p}<0,01)$.

Table 1. Delayed onset muscle soreness values

\begin{tabular}{|c|c|c|c|}
\hline & $\mathrm{N}$ & Mean & Std Dev \\
\hline $\begin{array}{c}\text { After 1st } \\
\text { competition }\end{array}$ & 20 & 5.05 & 2.31 \\
\hline $\begin{array}{c}\text { After 3rd } \\
\text { competition }\end{array}$ & 20 & 5.20 & 2.33 \\
\hline $\begin{array}{c}\text { After 5th } \\
\text { competition }\end{array}$ & 20 & 6.25 & 2.15 \\
\hline After 24 hours & 20 & 6.30 & 2.92 \\
\hline After 48 hours & 20 & 5.80 & 3.05 \\
\hline
\end{tabular}

Delayed onset muscle soreness values of the participants were evaluated before the first competition and after the 1st, 2nd, 5th competitions and after 24 and 48 hours, using Likert-type pain scale. And according to descriptive analyze results onset muscle soreness of the participants were found 5.05 after the 1st competition, 5.20 after the 3 rd competition, 6.25 after the 5 th competition, and 6.30 after 24 hours and 5.80 after 48 hours.

\section{Discussion}

This paper aimed to investigate muscle damage and following delayed onset muscle soreness for the wrestlers after one-day wrestling tournament consisted of 5 competitions. Analyze results revealed that creatine kinase levels of the wrestlers' significantly increased after the tournament $(\mathrm{p}<0.01)$. And according to descriptive analyze results it was seen that delayed onset muscle soreness of the wrestlers increased after all competitions, peaked after 24 hours and, after 48 hours it started to decrease. In his study Kayhan [12] indicated that when exposed to eccentric training creatine kinase level of the individuals' increases. According to his findings, a statistically significant increase in creatine kinase levels before and after exercise consisted of 10 cycles and 15 sets with their maxima. Besides delayed onset muscle soreness values significantly increased. Present findings are parallel to the findings of Kayhan [12].

In the study conducted by Barbas and colleagues, the investigated the effects of oneday wrestling tournament on physiological and performance adaptation of Greco-Roman wrestlers and similar to present findings they stated a significant increase in creatine kinase 
levels and delayed onset muscle soreness [4]. In their study, Ojala and Hakkinen specified similar findings to present findings and according to Ojala and Hakkinen [16] delayed onset muscle soreness for the athletes especially peaks after 24 hours of physical activity.

\section{Conclusion}

As a result of this study, it was found that one-day wrestling tournament causes muscle damage and delayed onset muscle soreness in elite wrestlers. It is thought that similar studies, conducted in wider and different groups, will be useful in order to minimize the reasons that cause muscle damage and delayed onset muscle soreness and maximize competition performance.

\section{References}

1. Atabek Çakır. H., Özdemir. F., C Vitamini İlavesinin Egzersiz Performansına Ve Kas Hasarına Etkisi. Celal Bayar Üniversitesi Beden Eğitimi Ve Spor Bilimleri Dergisi, 5(2) (2010).

2. Atalay Güzel, N., Effects of different resistance exercise protocols on nitric oxide, lipid peroxidation and creatine kinase activity in sedentary males, Journal of Sports Science and Medicine, 6, (2007).

3. Aydos. L., Taş. M., Akyüz. M., Ahmet Uzun, A., Genç Elit Güreşçilerde Kuvvetle Bazı Antropometrik Parametrelerin İlişkisinin İncelenmesi, Gazü Üniversitesi Beden Eğitimi Ve Spor Bilimleri Dergisi, Cilt.11, Sayı. 4, (2009).

4. Barbas. İ., ve ark., Physiological and performance adaptations Of Elite Greco-Roman Wrestlers During A One-Day Tournament, Eur. Apple Physiol 111, (2011).

5. Çoban. O., Güreşçilere uygulanan koenzim Q 10 Takviyesinin Kas Hasarı İle Eser Elementler Üzerine Etkisinin İncelenmesi, Erciyes Üniversitesi Sağlık Bilimleri Enstitüsü Beden Eğitimi Ve Spor Bilimleri Anabilim Dalı,Yüksek Lisans Tezi, Kayseri, (2011).

6. Erdoğan. M., Farklı Isı Koşullarında Uygulanan Maksimal Aerobik Yüklenmenin Kas Hasar1 ve Performans Üzerine Etkileri, Gazi Üniversitesi Sağlık Bilimleri Enstitüsü Beden Eğitimi Ve Spor Anabilim Dalı Doktora Tezi,Ankara, (2009).

7. Filiz. K., Gazi Üniversitesi Güreş Takımı İle Kara Harp Okulunda Güreşen Azeri Öğrencilerin Bazı Test Ölçüm Sonuçlarının Karşılaştırılması, Kastamonu Eğitim Dergisi, Cilt.II,No.3, (2003).

8. Garcia-Pallares. J., ve ark., Physical fitness factors to predict male Olympic wrestlingperformance, Eur J Appl Physiol, 111:1747-1758DOI 10.1007/s00421-0101809-8 (2011).

9. Harbili, S., Sıcak Stresin Ekzentrik Egzersizin Neden Olduğu Kas Hasarına Etkisi. Hacettepe Üniversitesi Sağlık Bilimleri Enstitüsü Spor Bilimleri ve Teknolojisi Programı Doktora Tezi, Ankara, (2007).

10. Hazar. S., Egzersize Bağlı İskelet Ve Kalp Kası Hasarı, Spormetre Beden Eğitimi ve Spor Bilimleri Dergisi, 2 (3) (2004).

11. Hazar. S., Erol. E., Gökdemir. K., Kuvvet Antrenmanı Sonrası Olușan Kas Ağrısının Kas Hasarıyla İlişkisi, Gazü Üniversitesi Beden Eğitimi Ve Spor Bilimleri Dergisi, 6(3) (2006).

12. Kayhan. M., Basketbolcularda Eksantrik Egzersiz Sonrası Oluşan Gecikmiş Kas Ağrısının Bazı Biyokimyasal Parametrelere Ve Şut Yüzdesine Etkisinin İncelenmesi Dumlupınar Üniversitesi Sağlık Bilimleri Enstitüsü Beden Eğitimi Ve Spor Anabilim Dalı Yüksek Lisans Tezi, Kütahya, (2014). 
13. Kılıç. T., Basketbol Turnuvasının Kas Hasarı Ve Toparlanma Süresine Etkileri, Gazi Üniversitesi Sağlık Bilimleri Enstitüsü Beden Eğitimi Ve Spor Anabilim Dalı Doktora Tezi, Ankara, (2010).

14. Koç. H., Effect Of Anaerobik Power On The Reaction Times Of Junior National Team Wrestlers, İnternational Journel Of Academic Research, Vol.5,No.1. (2013).

15. Ocak. Y., Tortop Y., Kadınlarda Halk Oyunları Çalışmalarının Bazı Fiziksel Uygunluk Parametreleri Üzerine Etkisinin İncelenmesi, Spor ve Performans Araştırmaları Dergisi,Cilt.4, Sayı.1, (2013).

16. Ojala. T., Hakkinen. K., Effect Of Tennis Tournament On Players Physical Performance, Hormonel responses,Muscla Damage And Recovery, Sports Sci. Med. Jun. 1; 12(2) (2013).

17. Şendil. A., Dehidrate Olmuş Bireylerde Step Machine Aletinde Yapılan Egzersize Bağlı Olarak Oluşan, Gecikmiş Kas Ağrısı (Doms) Üzerine İzotonik Spor İçeceklerinin Etkisi, Hacettepe Üniversitesi Sağlık Bilimleri Enstitüsü Spor Bilimleri Ve Teknolojisi Doktora Tezi, Ankara, (2008).

18. Şentürk. A., Kılınç. F., Şiktar. E., Şiktar. E., Hentbolcülere Uygulanan Aerobik Dayanıklılık ve Kuvvet Antrenmanlarının Deri Altı Yağ Ölçüm Değerleri Üzerine Etkisinin Araştırılması, Atatürk Journal Of Physicial Education And Sport Science, Cilt..10, Sayı.1,S.29-36.Erzurum, (2008).

19. Zaccakni.L., Antropometrics And Body Composition Of Italian National Wrestlers, Europen Journal Of Sport Science, 12, (2012). 